https://doi.org/10.18485/kud_kiaz.2019.ch29

Gunay Safarova, teacher, specialist AUL, Department of Foreign Languages, Teacher of Hebrew AUL, Israel and the Middle East Research Center, specialist gunaysafarova@yahoo.com +994518202766

\title{
MOUNTAIN JEWS LIVING IN AZERBAIJAN
}

\section{SUMMARY}

Jews in Azerbaijan consist of three distinct groups: Mountain Jews, Ashkenazi Jews, and Georgian Jews. Azerbaijan is home to some ethnic groups. The first synagogue in Baku was built in 1832. At present, more than 20,000 Jews live in Azerbaijan and there is always a good attitude to them in our country.

Key words: Mountain Jews, Red Town, synagogue, wedding customs, mourning traditions, Khazars

Mountain Jews are mentioned in Caucasian Jews in Azerbaijan and Dagestan. This group, also referred to as Caucasian Jews, is also referred to as East Caucasian Jews because they lived in the east of the Caucasus. The mountain Jews are believed to have lived in the Caucasus since ancient times. According to the belief, 10 tribes sent to exile in 722 $\mathrm{BC}$ by the Assyrians, some time later, migrated from southwestern Iran to Azerbaijan and lived here (2).

Azerbaijan has fallen to the attention of the world Jewish elite since 1810. At that time, in 1811, the first Ashkenazi began to settle down in Baku. In 1832 the first Jewish houses were built in Baku. Since 1870, began their flow to Azerbaijan. 
Since that time, Baku has started to produce oil and the flow of Jewish businessmen to Baku has increased.

The Red Village of Guba is settled and compactly inhabited by a large community of Mountain Jews.

Jews living in Azerbaijan have always been treated with good attitude and never have anti-Semitism cases.

According to Arthur Koestler, after the disintegration of the Caspian Hagans, the mysterious Khazars spread to Crimea, Ukraine, Hungary, Poland and Lithuania.

Most of the world scholars are concerned about the possibility of the Eastern European Jews, even the majority of the world's Jews, to be of the Khazar descent, not the Sami race. But this information has not been confirmed and is still being processed.

A small part of the Caspian Sea never left the mainland, the Caucasus. Today, they still live under the name of "Mountain Jews". In Azerbaijan and Dagestan there are villages where Mousavians live, saying that their ancestors are the Caspian. Most of the Khazars is believed to have migrated to Eastern Europe and joined to the Jews there (1, p.36).

The Caspian Sea, in 740, shocked the whole world and abandoned the ancient religions of Goy-Tengri (God) and chose the Museviism as their official religion. So why did they choose Museviism, not Islamic or Christianity, the most famous religions of that time? In many history books, this choice has been regarded as a strategic step taken by the Byzantine and the Muslims who seek to convert Christianity to the East and to those who seek to get out of the East, as well as to escape these two political pressures. For if they had accepted it, they would have melted away within them. But by choosing Museviism, they continued to be the third force. $(1$, p.37)

How the Khazars preserve their existence nearly 200 years after accepting the Museviism, we learn from the letter written by the King of the Khazar Joseph C. Jordi to a Jewish stateman Hasdai Ibn Shapruta. 
Xasday Ibn Shaprut was the vizier of Endelus's caliph. He was also a Jew who learns the existence of a "Jewish kingdom" in the North from the Chorosan merchants and useless ambassadors who came to Spain and are excited. This was a miracle for the Jews. Later, he learns that his name is Joseph. (1, p.31-32)

There are various opinions about the history and origins of mountain Jews in modern times. Some scholars say that mountain Jews originated in the VII century.

As it is known, the Khazars were the Turkish tribes who adopted Jewish religion. However, modern scholars say that the mountain Jews were Jewish captives during Assyrian and Babylonian occupation before our era. The Jewish religious books indicate that as a result of the occupation of Samira by Assyrians, Jews living in the territory of Galaxa, Habura, Kazan River, and the Midian Mountains are located in the present South Azerbaijan (3).

In general, it should be noted that the Azerbaijani lands have historically been a shelter for many nations as well as Jews.

Historically, Jews in Azerbaijan were mainly represented by Mountain Jews, Ashkenazi Jews and Georgian Jews in different groups.

Today, Jews living in Azerbaijan are divided into three groups: the oldest group of mountain Jews, the Ashkenazi Jews settled in the late 19th and early XX centuries, as well as during the Second World War, and a group of Georgian Jews settled in Baku in the early 20th century.

That is, in Azerbaijan, Jews are represented by three communities - Mountain Jews, Georgian Jews and European Jews (Ashkenazi) communities. They have schools, organizations, and synagogues in our country.

Since 2010, the construction of a new synagogue for Mountain Jews living in Azerbaijan has begun. The construction of a new synagogue for mountain Jews in need of reconstruction and capital rehabilitation in Baku in 2010 
was initiated, with the initiative and care of the President of Azerbaijan Ilham Aliyev. The opening ceremony of this synagogue for mountain Jews was held on April 5, 2011. It is located at, Alimardan Topchubashov str. 72, Nasimi district. This synagogue differs from other Jewish temples not only in Azerbaijan but also in the region due to its architectural characteristics and dimensions (4).

For many centuries, the mountainous Jewish community has lived in peace and tranquility among Muslims. They even speak the language of the Muslims. At the same time, Jews participated in wars for the lands of Azerbaijan and became martyrdom. One of the national heroes of Azerbaijan, Albert Aqarunov, who was martyred in the Karabakh war, was a mountain Jew (5).

The "Red Village" in Guba is the place where the mountain Jews live compactly. Today mountain Jews in Azerbaijan live mainly in Baku, Guba and Oghuz. There are synagogues in all three cities. Today, Mountain Jews live in peace in Azerbaijan (6).

The arrival and settling of Jews to Azerbaijan about 2,600 years ago. Throughout the centuries, local people have always enjoyed a positive and positive attitude towards the Jews who have lived in our country.

Jews living in Azerbaijan are mainly engaged in crafts, trade, medicine, teaching, etc. they have worked in such areas.

After the restoration of our independence, a new stage in the lives of national minorities, including Jews, has begun.

State supports for the protection of national minorities' rights and freedoms, their culture and language development has opened new opportunities for Jewish communities.

All the necessary conditions have been created for European Jews to perform religious services at a high level.

A school called "Shirmat Ha-Shem" for Jewish children has been opened in the Red Village, where Mountain Jews live compactly in Guba. Here are the Israeli teachers teaching Jewish national traditions. 
In October 2010, a synagogue belonging to the Mountain Jews Jewish community was put into operation (7). Holocaust is also celebrated in our country.

Jewish communities are considered the most active religious communities of the Republic of Azerbaijan.

In addition, at the Faculty of Oriental Studies at the Baku State University, as well as the Hebrew language at the Faculty of International Relations and Management of the Azerbaijan University of Languages are taught Hebrew. There are also Israeli and Middle East research center at the Azerbaijan University of Languages.

Weddings and mourning traditions of mountain Jews. Regarding the tradition of weddings and mourning of mountain Jews, it should be noted that most of these traditions coincide with our traditions. For many years, coexistence has also affected the similarity of traditions. In spite of their historic homelands, mountain Jews in Israel, as well as in our country, seek to preserve their national traditions. Members of the Mountain Jewish community hope to keep these traditions and hope for good times ahead.

Wedding Habit. The marriage was determined by marriage. Marriage relationships were sometimes determined by the families themselves at earlier ages. The girl was engaged at the age of 7 or 8 years old, her future husband. She helps her future mother-in-law in her home job, accustomed to her new family. If the bride's parents were dissatisfied with the girl's marriage with her, the boy's family would steal her.

When the boy's family arrives at the girl's home, the formal atmosphere is observed. While drinks are offered, the boy's family does not even touch a glass of water if has not received a positive response. The conversation is usually based on the gift of the bride. In the nineteenth century, the father of the bride gave the bride's father $1 \mathrm{cow}, 288 \mathrm{~kg}$ of wheat, $48 \mathrm{~kg}$ of bulgur, 20 chicken, about $3 \mathrm{~m}$ silk, and 1 white ravioli. Over time, this amount is agreed upon between the targets. Here are two factors: the financial situation of the parents and the appearance of the bride. 
After the wedding, the wedding ceremony is held before the wedding. The engagement ceremony was canceled until the 40s and 50s. Father's bride hugs the head of the bride and wore gold or silver necklace on her neck. The engagement ceremony in Azerbaijan is considered as a major part of the wedding ceremony: the terms of the marriage contract are read, blessed, and the bride covers the bride's head. The bride and groom drink wine, change their rings, and give them a silver necklace.

At the ceremony, the cup is not broken and the accidental breakdown of any item is considered a bad event. After the ceremony, the parents of the bride invite the bride to get acquainted with the house. A week later, he returned to his father's home. The bride and other holidays are given gifts to the bride. At the "Bexshey tebego" ceremony, the bride shows her neighbors and relatives. The wedding date is about a month ago. Traditionally, during this period, relatives come to each other. The preparation begins with preparation of clothes. Wedding festivals last 4-10 days. It was dependent on the father's financial situation and the wedding usually began on Wednesday.

On the first day of the wedding, guests gather at the bride's house. Gifts for the bride are brought. Then the ceremony is held, and the needle and silver are placed in the bowl, and the bride's hands and feet are drawn to the henna. On the second day of the wedding, she comes to cut her hair. Then they wear brides. The verse 137 of Surat al-Zabur is read. At this time, the bride and her parents, Ravvin, meet at a couple's home bride and write a Ketubbahi-marriage contract. This agreement determines the consent of the clerk.

Bridegroom comes with his relatives to take her bride. Bride's brother carries her mirror. When approaching the couple's to house, rice, porridge, and small coins are fertilized. Bridegroom's mother welcomes her bride with a honeycomb and squeezes the right hand of the bride. This tradition bring happiness, kindness and peace to the family. 
The bride and her relatives did not take part in the wedding, and they were given food in a separate room. Since the 1970s, marriage has changed gradually. Divorce was rarely found in mountain Jews.

Mourning habit. Death-related rituals play an important role in the Jewish community. Condolences to the dead are on Friday and Saturday. When it comes to spreading the news of death, not only relatives, but also foreigners come to their condolences. In this ritual candles are burned, and the Rabbi reads the Psalms. Dead ished, this ceremony may be in the yard, specially crafted tent or in the bedroom of the deceased.

Kəfən döşək ağından tikilir. Kişilər üçün geyimlərköynək, şalvar, kəllə papağı, əlcəklərdən, qadınlar üçün isə geyim və corabdan ibarətdir. Adətə görə, ölünün oğulları kəfən parçasından boyunlarına qayış taxırlar.

After being dead ready, six people are transported on the stretcher and every 25-30 steps people that carry this stretcher are replaced. Rabbi reads a prayer whenever the dead put on the floor. In the cemetery, half of the women are sent home and cooked.

If the dead is young man, there is no meat in the meal, but there are potatoes cooked in water, eggs, apples and dried fruits. If the dead is old, meat is given. By 70, everyone involved in the meal had to bring food. But this was slowly replaced by money. One of the relatives holds a list of people thar come to the mourning ceremony and sets the sum for each person.

Mutual friendship and cooperation between Azerbaijan and Israel are based not only on economic and strategic benefits but also on traditional historical and cultural roots. The peoples of Azerbaijan and Israel have always been able to demonstrate a common sample of mutual understanding and tolerance based on the difficult times of history (8).

As a Muslim country, the level of relations between Azerbaijan and Israel attract a lot of attention. From the Israeli point of view, relations with Azerbaijan are important because of 
the economic interests of the state, such as oil exports and arms exports, as well as Azerbaijan's neighborly relations with Iran. This gives Azerbaijan a geopolitical privilege before Israel.

On the other hand, there is no second example of Israel's close relationship with Islamic countries, and Tel Aviv uses it to change its image against the Islam in front of of the Islamic world.

The Jews, at every opportunity, show their relationship to their homeland by various activities. Of course, these Jews are also trying to admit that the Israeli state is a close friend of Azerbaijan, and for this case they use the press very well. Israeli journalists and political analysts frequently apply to Azerbaijani television, newspapers and news agencies with the financial support of the Jewish lobby to comment on the activities of the Jewish lobby and even incase events to the Jewish interests (9).

The Israelis have always shown great interest in Azerbaijani culture and they also show it now.

\section{Odəbiyyat}

Pınar Özgün, Hazarlar-Kayıp Kavim, CINIIUS YAYINLARI ARAŞTIRMA, Babıali Caddesi, No.14 Cağaloğlu-İstanbul, BİRINCİ BASKI: Kasım, 2013, ISBN 978-605-127-810-0, 135 səh.

https://books.google.nl/books?id=1I0VBgAAQBAJ\& $\mathrm{pg}=\mathrm{PA} 36 \& 1 \mathrm{pg}=\mathrm{PA} 36 \& \mathrm{dq}=\mathrm{Da} \% \mathrm{C} 4 \% 9 \mathrm{~F}+\mathrm{yahudileri} \&$ source $=\mathrm{b} 1 \&$ ots $=$ NZ6OvS5FkV\&sig=7aoRbQpurB2d 9j6tM5vJ7uu w mew $\& \mathrm{~h} 1=\mathrm{n} 1 \& \mathrm{sa}=\mathrm{X} \& \mathrm{ved}=0 \mathrm{ahUKEwi} 7 \mathrm{mszc} 55$ Z A A WC 6QKHaAfALsQ6AEIeTAI\#v=onepage \&q=Da\%C4\%9F $\% 20$ yahudileri\&f=false

https://tr.wikipedia.org/wiki/Da\%C4\%9F_Yahudileri

http://publika.az/news/qirmizi/9197.html

http://scwra.gov.az/structure/18/?\%E2\%80\%9CDa\%C4\%9F\%20 y\%C9\%99hudil\%C9\%99ri\%E2\%80\%9Dnin\%20sinaqoqu

https://istiraki.blogspot.com/2009/10/baku-ve-yahudiler.html

http://publika.az/news/qirmizi/9197.html

http://scwra.gov.az/branch/26/?

http://www.xalqqazeti.com/az/news/politics/80590

http://insamer.com/tr/azerbaycanda-israil-algisi-ve-etkisi_713. html 


\section{РЕЗЮМЕ}

Евреи в Азербайджане состоят из трех различных групп: горских евреев, ашкеназских евреев и грузинских евреев. В Азербайджане проживают более мелкие общины. Первая синагога в Баку была построена в 1832 году. В настоящее время в Азербайджане живет более 20000 евреев, и всегда есть хорошее отношение к ним в нашей стране.

Ключевые слова: Горские евреи, Красная Слобода, Синагога, Свадебные Обычаи, Траурные Традиции, Хазары. 